\title{
Evaluation of ectomycorrhizal respiration for remediation of pesticides in forestry
}

\begin{abstract}
The ectomycorrhizal (ECM) can be used on forest seedlings production. This work raises the possibility that these microorganisms can also assist the degradation of organic molecules of pesticides registered on forestry. This study aimed to evaluate the microbial respiration of forest substrate inoculated with ECM, since the effect could be important in agroquemichal remediation. There was used a completely randomized design with two treatments and six replications. As a control (T0), was used the commercial substrate. As treatment 1 (T1), the substrate was mechanically mixed with mycorrhizal inoculant. It was possible to infer that the control group evolved $8,4167.10^{-4} \mathrm{~mol} \mathrm{CO}_{2} \cdot \mathrm{dm}^{-3}$.day, and treatment with mycorrhizal soil, $1,0202 \cdot 10^{-3} \mathrm{~mol} \mathrm{CO}_{2} \cdot \mathrm{dm}^{-3}$. day. Notably, the $\mathrm{T} 1$ evolved a little more, probably due to mycorrhizal inoculated, but without significant difference. It presents arguments about the potential use of ECM roots remediation, and also contextualized for integrated pest management on forestry, given the imposition of forest certification programs to reduce chemical control.
\end{abstract}

Keywords: bioremediation, phytosanitary defense, forest health protection, forest certification, forestry
Volume 8 Issue 6 - 2018

\author{
Alvaro Boson de Castro Faria \\ Forest Engineering Department, Federal University of \\ Technology, Brazil
}

\begin{abstract}
Correspondence: Alvaro Boson de Castro Faria, Federal University of Technology, $4^{\text {th }} \mathrm{km}$ of Boa Esperança Road, Dois Vizinhos, Paraná, Brazil, Tel 463536 84l8,
\end{abstract}

Email alvarab@utfpr.edu.br

Received: November 29, 2017 | Published: November 26, 2018
Abbreviations: ECM, The ectomycorrhizal fungi; T0, control group; T1, treatment 1; SMR, soil microbial respiration; MBC, microbial biomass carbon; FSC, forest stewardship council

\section{Introduction}

The microorganisms present in the soil can be phytopathogenic causing damages in crops, but they can also be beneficial, like the mycorrhizal fungi and the rhizobacteria, that favor the development of the plants. Ectomycorrhizal fungi (ECM), sometimes present in the roots of Pinus spp. and Eucalyptus spp., in many cases, may contribute to the growth of forest essences.

According to Perez-Moreno \& Read, ${ }^{1}$ until recent times the ability of ectomycorrhizal fungi (ECM) to mobilize and recycle nutrients from soil organic matter had received little attention. In fact, ECMs can produce a wide variety of enzymes capable of degrading substrates that are part of organic soil materials (ibid.). Monteiro et al., ${ }^{2}$ for example, evaluated that the ECM inoculum was tolerant to glyphosate, and that the possibility of pesticide remediation could be further studied.

Faria et al., ${ }^{3}$ presented the potential of using ectomycorrhizae in pesticide remediation. However, the theme becomes interesting when analyzing the context of sustainability in the forest sector, which is constantly evaluated by certification organizations such as the Forest Stewardship Council (FSC), regarding the corporate policy for reducing the use of chemicals in the management of plantations.

With the hypothesis that the use of ECM could favor the remediation of pesticides by the roots of the forest species, it would be necessary to evaluate the Soil Microbial Respiration (SMR). The larger the SMR, the more $\mathrm{CO}_{2}$ is produced by the micro biota, indicating a probable organic degradation of pollutants in the soil. Anderson \& Domsch ${ }^{4}$ proposed the calculation of the Metabolic Quotient, which establishes the relationship between $\mathrm{CO}_{2}$ accumulated in Soil Microbial
Respiration (SMR) and Microbial Biomass Carbon (MBC), which would allow inferences to be made about the activity of remediation of ECM, of inoculation trials on forest seedlings. In this perspective, this work had as objective to evaluate the microbial respiration of the substrate of forest seedlings inoculated with ectomycorrhizae, and to provide elements for the discussion about the feasibility of remediation of agrochemicals used in the forest sector.

\section{Case presentation}

The collection of mycorrhizal inoculant in the soil was carried out based on the method described by Inoue. ${ }^{5}$ It was collected at the base Pinus taeda L. located at the Campus of Federal University of Technology, in the southwestern of Paraná. The existence of mycorrhizae in the soil was verified by the simple examination of the roots. The material was stored in a freezer, until the moment of its experimental use.

A completely randomized experimental design with two treatments and six replicates was used. As control (T0), $90 \mathrm{~g}$ of the commercial substrate was used for the production of tree seedlings, brand Mecplant ${ }^{\circledR}$. Then another $90 \mathrm{~g}$ of substrate was mechanically mixed with $10 \mathrm{~g}$ of the previously thawed mycorrhizal inoculum (Treatment 1, T1). For the development of the microbiota, the vessel were closed and conditioned in a photoperiod for 11days, in which humidity maintenance was controlled by spraying $30 \mathrm{ml}$ of water inside, every three days. The temperature was adjusted to $28^{\circ} \mathrm{C}$, with 12 hour lighting intervals.

For the determination of humidity, two aliquots of the fresh soil samples, dried at $105^{\circ} \mathrm{C}$ to the constant weight (in a greenhouse for sterilization and drying) were weighed and dried and the humidity was determined by gravimetric. The data did not need to be transformed for the homogenization of the variances, which allowed the use of the Anova and made possible its comparison by the test of Tukey to $5 \%$ of probability. 
The SMR analytical calculation was performed based on the respirometry technique described in Souza et al., ${ }^{6}$ Pires et al., ${ }^{7}$ Pena et al. ${ }^{8}$ It was weighed $15 \mathrm{~g}$ of soil per replicate, and placed in vials of $600 \mathrm{~mL}$. In each vessel, a beaker with $5 \mathrm{~mL}$ of $0.5 \mathrm{~mol} \mathrm{~L}^{-1} \mathrm{NaOH}$ was placed. They were hermetically sealed and incubated (chamber with thermometer and photoperiod) at $28^{\circ} \mathrm{C}$ and 12 hour lighting intervals.

For the titration, the beaker cups of the vials were withdrawn with tweezers, and a drop of the $1 \%$ phenenphthalein indicator was added to each. The unused $\mathrm{NaOH}$ during incubation of the soil sample was then titrated with $0.5 \mathrm{~mol} . \mathrm{L}^{-1} \mathrm{HCl}$ until the coloration disappeared. The amount of $\mathrm{HCl}$ spent on the titration was recorded. The amount of $\mathrm{CO}_{2}$ released per gram of dry soil was calculated for the four day incubation period. Further, the experimental procedure was supplemented with blank (non-incubated $\mathrm{NaOH} 0.5$ mol. $\mathrm{L}^{-1}$ ).

\section{Discussion}

There are indications that an organic matter consumption of the substrate was actually produced by the micro biota present, with the formation of $\mathrm{CO}_{2}$ within the flasks, since there was a significant difference between treatments (T0 and $\mathrm{T} 1)$ and the blank ( $\mathrm{F}=12,15^{*}$, $\mathrm{p}<0.05$ ). However, there were no significant differences between the control and treatment with mycorrhizal soil (Table 1).

Table I Treatment titration results

\begin{tabular}{ll}
\hline Treatment' $^{\prime}$ & Titled Volume (mL) \\
\hline Control group (T0) & $4.92 \mathrm{a} \pm 0,13$ \\
Soil with inoculation of mycorrhiza (TI) & $4.85 \mathrm{a} \pm 0,17$ \\
Blank proof $\left(\mathrm{NaOH} 0,5\right.$ mol. $\left.\mathrm{L}^{-1}\right)$ & $5.25 \mathrm{~b} \pm 0,15$ \\
$\mathrm{~F}$ & $12,15 *$ \\
\hline
\end{tabular}

'Means with different letters in the columns are significantly different by the Turkey test with a probability of $5 \%(*=$ significant, ns $=$ not significant)

It is possible to infer that the soil of the control evolved 8.4167.10${ }^{4} \mathrm{~mol} \mathrm{CO} \cdot \mathrm{dm}^{-3} \cdot \mathrm{day}^{-1}$, and the treatment with mycorrhized soil, 1 , $0202.10^{-3} \mathrm{~mol} \mathrm{CO}_{2} \cdot \mathrm{dm}^{-3}$. day ${ }^{-1}$. Notably, $\mathrm{T} 1$ evolved a little more $\mathrm{CO}_{2}$, probably due to the respiration of inoculated mycorrhizae. All these are quantitative parameters that can be used comparatively in future experiments.

The greater the amount of $\mathrm{HCl}$ spent in the titration to the point of "turning" (disappearance of the pink color), the greater the amount of $\mathrm{NaOH}$ needed to balance this reaction. In other words, the smaller the amount of $\mathrm{NaOH}$ transformed in $\mathrm{Na}_{2} \mathrm{CO}_{3}$ in the process of $\mathrm{CO}_{2}$ uptake evolved from soil microbial respiration. For the blank, $\mathrm{NaOH}$ was available in its completeness since it was not incubated in the treatment containers.

The inoculated mycorrhizae may have increased respiration in the T1, evidenced by the smaller titrated volume $(4.85 \pm 0.17 \mathrm{~mL})$. It is valid to repeat these tests, quantifying this inoculum, in order to define the parametric limits. It is also recommended that the addition of saturated $\mathrm{BaCl}_{2}$ in the beakers as a catalyst for the reaction between $\mathrm{NaOH}$ and $\mathrm{CO}_{2}$ evolved, as used by Pires et al. ${ }^{7}$

For Souza et al., ${ }^{6}$ the soil microbial activity is directly related to its environmental factors, such as humidity, oxygenation, $\mathrm{pH}$, temperature, nutrients, among others. The moisture content of the samples resulted in an average of $25.8 \%$ for T0 and $24.3 \%$ for T1 (Table 2). The other environmental factors can be considered homogeneous, since the same soil was used in both treatments.

Table 2 Experimental soil moisture content when incubated

\begin{tabular}{lllllll} 
& \multicolumn{2}{l}{ Wet weight(g) } & \multicolumn{2}{l}{ Dry weight(g) } & \multicolumn{2}{l}{ Moisture content(\%) } \\
\cline { 2 - 7 } & T0 & T I & T0 & T I & T0 & T I \\
\hline Sample I & 18 & 21 & 13 & 15 & $27.80 \%$ & $28.60 \%$ \\
Sample 2 & 21 & 20 & 16 & 16 & $23.80 \%$ & $20.00 \%$ \\
Mean & 19.5 & 20.5 & 14.5 & 15.5 & $25.80 \%$ & $24.30 \%$
\end{tabular}

Analytically, Souza et al., ${ }^{6}$ provide the following formula for the calculation of the amount of $\mathrm{CO}_{2}$ evolved from each sample $\left(\mathrm{C}_{\text {molc }}\right.$ of $\mathrm{CO}_{2}$ per $\mathrm{dm}_{3}$ of soil), used in this study:

$\mathrm{C}_{\text {molc }} \mathrm{CO}_{2} \cdot \mathrm{dm}_{-3}$ of soil $=[(\mathrm{B}-\mathrm{T}) . \mathrm{N}$. f. V $] /$ AT

Where:

$\mathrm{B}=$ white titre, $\mathrm{ml} \mathrm{HCl}$

$\mathrm{T}=$ treatment titre, $\mathrm{ml} \mathrm{HCl}$ of soil

$\mathrm{N}=$ normality of $\mathrm{HCl}\left(\right.$ eq-g L $\left.\mathrm{L}^{-1}\right)$

$\mathrm{f}=0,9998$ (acid correction factor)

$\mathrm{V}=$ volume of $\mathrm{NaOH}$ used to capture $\mathrm{CO}_{2}(\mathrm{ml})$

$\mathrm{AT}=$ aliquot to be titrated $(\mathrm{ml})$

According to Meharg 9 when considering root remediation and other forms of biological manipulation of contaminated soils, corrective organisms must at least meet three important requirements: the pollutant must be bioavailable to the remedial organism; it must be tolerant to the pollutant present in the concentrations found in the site to be corrected; and, the organisms must possess the enzymatic capacity to degrade the pollutants of interest. Root remediation has the advantage of causing low disturbance and environmental impact on the soil to be decontaminated..$^{10}$

The interactions of mycorrhizae with soil organisms are unavoidable, but they have been little studied. ${ }^{11}$ However, it is not known whether the nutritional source of ECMs is the host plant or soil organic matter. ${ }^{12}$ Little is known about the functional diversity of ECM enzymes. ${ }^{13}$ For Meharg \& Cairney, ${ }^{10}$ the degradation efficiency of a pollutant will depend on a number of factors, including fungus growth rates, growing conditions, incubation time and nutrient contents.

Cabello ${ }^{13}$ emphasizes that in field experiments, the concentration of propagules in the soil will be a determinant factor in the efficiency of the remediation, and that the studies on rhizorremediation should focus on which exudates are produced by the roots of the plants. In this way, it corroborates the statement of Finlay ${ }^{14}$ that among the new trends in mycorrhizal research, they had highlighted the studies on the interaction of the extrarradicular mycelium with organic and inorganic soil substrates. Meharg 9 mentions that ECM enzymes are excreted extracellular. This statement is important because the use of ECM for bioremediation can also produce wastes.

The proposed studies are important for the development of theories on agricultural and forest sustainability. In this line of reasoning, Meharg \& Cairney ${ }^{10}$ point out those silvi cultural techniques must be 
considered to optimize remediation, but there are still few examples of practical application. The use of bioremediation technologies is still in its infancy (ibid.), but the idea is valid for situations in which the site allows long-term soil recovery. ${ }^{9}$

In the case of certified forest management, brazilian companies have not yet been able to relinquish the use of agrochemicals in the implementation and maintenance of stands, such as weed control herbicides, and chemicals for the control of leaf-cutting ants (Atta spp. and Acromyrmex spp.), a common pest of South America, and which still causes many damages in the forestry. For this pest, there is no efficient biological control yet. In spite of this fact, the chemical strategies of integrated management of the biotic agents that attack the forest plantations are the object of FSC alert, which considers them as the last alternative among the available techniques, permanently putting pressure on the companies not to use them anymore. In face of this reality, the implementation of programs to reduce the use of these pesticides is required, in the process of continuous improvement of the evaluation of renewal of the certification.

For the context of the integrated management of cutter ants and weeds in forest crops, the level of economic damage, a parameter used to affirm the need to develop control actions (with natural, mechanical or chemical methods), is carried out mainly in order to evaluate the costs of forest implantation and maintenance, especially related to seedling mortality and replanting, and not to the reduction of growth caused by pests over time. It is in this sense that research on remediation by ECM, Formicidae baits and low toxicity herbicides, already licensed for the sector, is necessary. In this way, it is believed that these studies can validate the decision making of the use of these products, as viable strategies for the forest sustainability.

The development of technologies on the verification of ECM remediation of authorized pesticides in the forestry may contribute to the determination and confirmation of the best practices of implementation and forest maintenance, even preventively, in line with the environmental safety of the practices used in this productive sector.

\section{Acknowledgments}

For the Laboratory of Forest Soils at the State University of the Western Center, for providing the materials used in the chemical analyzes.

\section{Conflicts of interest}

Author declares that there is no conflicts of interest.

\section{References}

1. Perez-moreno J, Read DJ. Los hongos ectomicorrízicos, lazos vivientes que conectan y nutren a los árboles en la naturaleza. INCI. 2004;29(5):239-247.

2. Monteiro PHR, Faria, ABC, Auer CGA, et al. Estudo sobre a viabilidade de remediação de pesticidas por ectomicorrizas e avaliação da sua tolerância em exposição ao glifosato. In: Fertbio, editor. Brazil; 2012.

3. Faria ABC, Monteiro PHR, Auer CG, et al. Ectomycorrhizal use for forest bioremediation. Ciência Florestal. 2017;27(1):21-29.

4. Anderson TH, Domsch KH. Determination of eco physiological maintenance carbon requirements of soil microorganisms in a dormant state. Biology and Fertility of Soils. 1985;1(2):81-89.

5. Inoue MT. Ensaio comparativo para dimensionar as influências causadas pela inoculação de fungos micorrízicos em mudas de Pinus taeda L. em relação à quantidade de inóculo presente no solo. Floresta. 1972;4(1):6368 .

6. Souza AP, Ferreira FA, Silva AA, et al. Respiração microbiana do solo sob doses de glyphosate e de imazapyr. Planta daninha. 1999;17(3):387-398.

7. Pires FR, Souza CM, Silva AA, et al. Fitorremediação de solos contaminados com herbicidas. Planta Daninha. 2003;21(2):335-341.

8. Peña MLP, Marques R, Jahnel MC, et al. Respiração microbiana como indicador da qualidade do solo em ecossistema florestal. Floresta. 2005;35(1):117-127.

9. Meharg AA. The potential for utilizing mycorrhizal associations in soil bioremediation. In: Gadd GM. Editor. Fungi in Bioremediation. 1st ed. Cambridge: Cambridge University Press; 2001. p. 445-455.

10. Meharg AA, Cairney JWG. Ectomycorrhizas extending the capabilities of rhizosphere remediation? Soil Biology and Biochemistry. 2000;32(1):1475-1484.

11. Perez-moreno J, Read DJ. Los hongos ectomicorrízicos, lazos vivientes que conectan y nutren a los árboles en la naturaleza. INCI. 2004;29(5):239-247.

12. Treseder KK, Torn MS, Masiello CA. An ecosystem-scale radiocarbon tracer to test use of litter carbon by ectomycorrhizal fungi. Soil Biology and Biochemistry. 2006;38(1):1077-1082.

13. Cabello MN. Mycorrhizas and hydrocarbons. In: Gadd GM, editor. Fungi in Bioremediation. 1st ed. Cambridge: Cambridge University Press; 2001. p. $456-471$.

14. Finlay RD. Mycorrhizal symbiosis: myths, misconceptions, new perspectives and future research priorities. Mycologist. 2005;19(3):90-95. 